\title{
Best Management Practices in Northern Agriculture: A Twelve-Year Rotation and Soil Tillage Study in Saguenay-Lac-Saint-Jean
}

\author{
Maxime Charles Paré ${ }^{a}{ }^{*}$, Jean Lafond ${ }^{b}$, And Denis Pageau ${ }^{b}$ \\ a Département des sciences fondamentales, Université du Québec à Chicoutimi, Saguenay, QC, \\ Canada, G7H 2B1; * Corresponding author. Tel.: +001 418-545-5011; E-mail address: \\ maxime_pare@uqac.ca \\ ${ }^{\mathrm{b}}$ Agriculture and Agri-Food Canada, Soils and Crops Research and Development Center, Normandin, \\ QC, Canada, G8M 4K3.
}

\section{Key words}

Barley; Canola; Chisel plough; Field pea; Moldboard plough; Reduced tillage; Soil quality; Sustainable agriculture

\section{Abstract}

In the northern agroecosystem of Saguenay-Lac-Saint-Jean, cash crops such as barley, canola, and field pea are gaining popularity over traditional perennial crops like alfalfa. However, very little information is available on the relatively long-term effect of different crop rotations and soil tillage practices on crop yields and soil quality parameters. This study was conducted at the Normandin Research Farm of Agriculture and Agri-Food Canada. Five rotation types [1: Canola-Barley-Barley-Pea (C-B-B-P); 2: Canola-Pea-Barley-Barley (C-P-B-B); 3: Canola-Barley-Pea-Barley (C-B-P-B); 4: Pea monoculture; and 5: Barley monoculture] and two soil tillage practices [1: Chisel plough (CP) and 2: Moldboard plough (MP)] were evaluated. Canola monoculture of was not included. The study began in 1999 on a former alfalfa field and ended in 2010 after three four-year rotation cycles. Barley monoculture decreased yields by $600 \mathrm{~kg} \mathrm{ha}^{-1}$ in the last five years, whereas field pea monoculture decreased yields by about $1000 \mathrm{~kg} \mathrm{ha}^{-1}$ in most years. Barley monoculture did not significantly reduce grain yields compared to C-B-B-P and C-P-B-B, highlighting the importance of alternate crops every year. Soil tillage (CP versus MP) did not significantly affect yields for all crops in most years; and when 
it did have an effect, it showed inconsistencies by either increasing or decreasing grain yields. Soil tillage also had insignificant impact regardless of the rotation type involved. Rotation type and soil tillage had insignificant effect on soil organic matter content, whereas CP increased nitrate and phosphorus content in the $0-20 \mathrm{~cm}$ soil layer. Rotation type had insignificant impact on soil physical properties, whereas CP improved soil water conductivity by $0.03 \mathrm{~cm} \mathrm{hr}^{-1}$ for C-B-B-P and barley monoculture. Compared to MP, CP improved soil macro-aggregate (2-6 mm) stability to water as well as aggregate mean weight diameter by about $15 \%$ for most of the rotations.

\section{Introduction}

In the northern agroecosystem of Saguenay-Lac-Saint-Jean, cash crops such as barley, canola, and field pea are gaining popularity over traditional forages such as alfalfa, timothy and clover. In 1986, annual cash crops occupied approximately $20 \%$ of the cultivated land (Tabi et al., 1990), whereas in 2011, cash crops grew on approximately 39\% (49 000 ha) of the cultivated areas (Statistique Canada, 2013). In the same period (1986 to 2011), perennial crops declined by $25 \%$ (from 66 to $41 \%)$.

The use of mixed crop rotations reduced year-to-year variability in yields for the overall rotation (Brandt and Zentner, 1995). The development of appropriate rotation systems with several adapted crops has the potential to provide better long-term incomes to farmers. Better knowledge of appropriate soil and plant best management practices are essential in order to maintain or improve crop profitability, food security, soil quality, and the environment in agroecosystems (Fageria, 2002). Good soil quality not only produces good crop yields, but also maintains environmental quality and consequently plant, animal, and human health (Fageria, 2002). Producers in Quebec, particularly in Saguenay-Lac-Saint-Jean, recognize the importance of adequate crop diversity and soil tillage for maintaining a sustainable food production system, but lack details on the effect of various 
combinations of these management practices. Furthermore, the northern climate of Saguenay-LacSaint-Jean restricts technologies and techniques suitable elsewhere in Quebec or Canada. Unlike other southern parts of Canada, winter cover crops are not often used in Saguenay-Lac-Saint-Jean simply because harsh weather conditions in fall (after harvesting) limit their implantation. One of the main challenges for sustainable agriculture in the region is therefore to identify best management practices and incorporate these practices into rational economic management systems.

Crop rotations and reduced tillage are commonly recommended for sustaining crop production and improving soil quality. Improving grain production with crop rotation is dependent upon the selection of crop species and subsequent alterations in pest populations and residual fertility related to soil quality (Arshad et al., 1999). Plants may modify soil structure by affecting many stabilisation processes throughout soil hydrological conditions and rhizodepositions (Angers and Caron, 1998). Angers and Mehuys (1988) found that, compared to fallow, only barley and alfalfa improve water stable aggregates, whereas corn has very limited effect. In Australia, Chan and Heenan (1996) found that canola creates more porous soils (low bulk density and high water infiltration) as well as more water stable aggregates compared to field pea and barley. Reduced tillage is also known to improve soil moisture retention in arid and semi-arid climates such as those found in North America (Holland, 2004). However, management practices effects on soil quality and nutrient cycles can be influenced by both local soil and climatic conditions (Soon and Arshad, 2005).

In Saguenay-Lac-Saint-Jean where climate conditions are both cold and wet, very little information is available on the long-term effect of different crop rotations and soil tillage on crop yields and soil quality parameters. The main objective of this study is to determine the best management practices related to annual crop rotation and soil tillage. The specific aims are to 
quantify the long-term effects of annual crop rotations and soil tillage practices on agronomic performance and soil chemical and physical properties.

\section{Material and Methods}

\subsection{Experimental design and treatments}

This study was conducted at the Normandin Research Farm of Agriculture and Agri-Food Canada, located in the northern area of Saguenay-Lac-Saint-Jean, Quebec, Canada $\left(48^{\circ} 50^{\prime} \mathrm{N}\right.$, $72^{\circ} 33^{\prime} \mathrm{W}$ ). The experimental trials were established on an Eluviated Gleysolic silty clay soil (Labarre soil series) composed of approximately $49 \%$ clay and $43 \%$ silt. The Labarre soil series is formed from flat lacustrine silt particles deposited on marine clay sediments at the bottom of the Laflamme glacial sea ( 10 000 B.P.); it covers approximately 4600 ha of Saguenay-Lac-Saint-Jean (Lamontagne and Nolin, 1997). The climate of the area is cold and wet with about $827 \mathrm{~mm}$ of precipitation (snow and rain) annually, whereas the growing season (from May to August) has a mean temperature of $14.0^{\circ} \mathrm{C}$ and approximately $344 \mathrm{~mm}$ of rain (Environment Canada, 2013; Lafond and Ziadi, 2011).

In the fall of 1998, a four year-old alfalfa (Medicago sativa) field was killed using glyphosate and plant residues were buried by MP. In the spring of 1999, annual cash crops were seeded. A total of five rotation types including canola, barley, and field pea were evaluated (Table 1). Each sequence of all four-year rotations was included each year (Table 1). Each experimental rotation unit was separated in two parts (two $80 \mathrm{~m}^{2}$ ) in order to have two distinct soil tillage practices [MP (Sanderum with 5 furrow ploughs; $25 \mathrm{~cm}$ deep) and CP (International 5500 with 9 shank springs; $15 \mathrm{~cm}$ deep)]. Both types of tillage were performed in the fall of each year (September to October), about one month after harvesting. All treatments were repeated four times, which allowed a total of 112 experimental units per year (14 rotation sequences $\times 2$ tillage practices $\times 4$ repetitions). Three cycles 
of four-year rotations were performed during the twelve years (Table 1). The same tractor was used for all treatments throughout the study.

Barley (Hordeum vulgare, Labelle ${ }^{\circledR}$ ) was seeded at a rate of about $175 \mathrm{~kg} \mathrm{ha}^{-1}$. Grassy weeds were controlled by tralkoxydim (e.g., Achieve ${ }^{\circledR}$ ), broadleaf weeds by bromoxynil and MCPA (e.g., Bructril ${ }^{\circledR}$ ). Field pea (Pisum sativum, Carneval ${ }^{\circledR}$ ) was seeded at a rate of about $290 \mathrm{~kg} \mathrm{ha}^{-1}$ and Metribuzin (e.g., Sencor ${ }^{\circledR}$ ) was used for weed control. Approximately 15 days before harvesting, Dibromide salt (e.g., Reglone ${ }^{\circledR}$ ) was used for haulm destruction. Canola (Brassica napus, Hyola $401{ }^{\circledR}$ for the first two rotation cycles and Hyola $357 \mathrm{RR}{ }^{\circledR}$ for the third) was seeded at a rate of about $6 \mathrm{~kg}$ $\mathrm{ha}^{-1}$ and glyphosate was used to control all weeds. In addition, insecticides (e.g., Pounce $384{ }^{\circledR}$ ) were used to control insect pests such as diamondback moths and flea beetles, when necessary. The stubbles were left on the field and buried according to the soil tillage practices. All fertilization application rates were determined according to the "Conseil des productions végétales du Québec" (CPVQ, 1996), which was the agronomic fertilisation standard in Quebec in 1999. Nitrogen, phosphorus, and potassium fertilizer rates were adjusted each year according to soil analysis and previous crop contribution. For instance, from a previous crop of pea, $\mathrm{N}$ rate was reduced to 50 and $60 \mathrm{~kg} \mathrm{ha}^{-1}$ for barley and canola respectively.

\subsection{Agronomic performance}

All crops were harvested at the end of the summer (late August to early September). Grain yields were determined on an area of about $26 \mathrm{~m}^{2}$ in the middle of each experimental unit using a plot harvester (Wintersteiger, Salt Lake City, USA).

\subsection{Soil chemical properties}

A thoroughly mixed composite of three soil samplings was made for each experimental unit. Soils were sampled at two depths $(0-20 \mathrm{~cm}$ and $20-40 \mathrm{~cm})$ using a $55 \mathrm{~mm}$ diameter soil auger in 
spring, the day before the first fertilizer applications, and in fall, one week after harvesting. All

samples were air-dried and 2-mm sieved, except for soil nitrate determination where all soil samples were kept frozen at $-20^{\circ} \mathrm{C}$ until analysis.

Soil organic matter was determined by chemical oxidation (Skjemstad and Baldock, 2008). Soil nitrates were extracted with a $2 \mathrm{M} \mathrm{KCl}$ solution (Maynard et al., 2008) and then determined colorimetrically (Lachat, Quickchem Method 10-107-04-1-B). Soil phosphorus was extracted with a Mehlich-3 solution (Mehlich, 1984) and then determined colorimetrically (Lachat, Quickchem Method 15-501-03).

\subsection{Soil physical properties}

Soil physical properties were determined twice per year, in spring (15 days after crop seeding) and in fall (15 days after harvesting). Three sampling locations per experimental unit were randomly selected. For each sampling locations, soil bulk density $(0-10 \mathrm{~cm}$ depth) was determined using the cylinder method (Hao et al., 2008). Soil water infiltration (saturated water conductivity) was determined in the laboratory according to the Reynolds (2008) procedure. Soil gravimetric water content (0-10 cm depth) was determined following the Topp et al. (2008) procedure. Soil wetaggregate stability (0-20 cm depth) was determined by using the water sieving method (Angers et al., 2008). The soil bulk density and water infiltration were determined with the same soil core, whereas soil gravimetric water content and wet-aggregate stability were measured with another soil sample.

\subsection{Statistical analysis}

Generalized linear mixed models were used for variance analysis. For soil chemical properties, variance was partitioned into five factors: 1) Rotation cycle (cycle 1: 1999-2002; cycle 2: 2003-2006; cycle 3: 2007-2010); 2) Rotation type (Canola/Barley/Barley/Pea; Canola/Pea/Barley/Barley; Canola/Barley/Pea/Barley; Pea monoculture; Barley monoculture); 3) Soil tillage (CP; MP); 4) Date of 
sampling (Spring; Fall); and 5) Depth of sampling $(0-20 \mathrm{~cm} ; 20-40 \mathrm{~cm})$. Year, rotation type, and soil tillage were used for agronomic performances, whereas rotation cycle, rotation type, soil tillage, and sampling date were used for soil chemical and physical properties. Rotation type was analysed as random factor, whereas rotation cycle (or year), soil tillage, sampling depth, and sampling date were used as fixed factors (Gbur et al., 2012). Normality and homogeneity of the variance were verified before statistical analysis was done. All statistical analysis were performed using the IBM SPSS for Windows software, Version 21.0 (IBM Corp., 2012).

\section{Results}

\subsection{Agronomic performance}

\subsubsection{Barley}

Compared to the C-B-P-B rotation, barley monoculture decreased yields by $600 \mathrm{~kg} \mathrm{ha}^{-1}$ in the last five years, whereas it had insignificant impact in the first seven (Fig. 1). Monoculture did not significantly reduce grain yields compared to C-B-B-P and C-P-B-B rotations - where barley was cultivated two years in a row - (Fig. 1), highlighting the importance of alternate crops every year. Soil tillage had minimal and inconsistent effects on barley grain yield. Soil tillage had insignificant effect during eight years, whereas CP decreased yields by about $350 \mathrm{~kg} \mathrm{ha}^{-1}$ in 2001,2004 , and 2008, and increased yields by $250 \mathrm{~kg} \mathrm{ha}^{-1}$ in 2010 (Fig. 1). Although MP tended to perform better than CP when barley was cropped in monoculture, soil tillage had insignificant impact regardless of the rotation type

(Fig. 1). From year one to year two, there was a strong decrease in barley yields by $1700 \mathrm{~kg} \mathrm{ha}^{-1}$, whereas barley yields tended to stabilize thereafter (Fig. 1).

\subsubsection{Field pea}

Rotation types involving three crops performed significantly better by about $1000 \mathrm{~kg} \mathrm{ha}^{-1}$ than monoculture in 2002, 2004, 2006, 2007, 2009 and 2010 (Fig. 1). When other crops were included, 
rotation types had insignificant effect on field pea yields (Fig. 1). As for barley, soil tillage had minimal and inconsistent effects on field pea grain yield over the years. Indeed the effect was minimal for a period of eight years, whereas CP decreased yields by about $250 \mathrm{~kg} \mathrm{ha}^{-1}$ in 2001, 2008 and 2010, and increased yield by $300 \mathrm{~kg} \mathrm{ha}^{-1}$ in 2002 (Fig. 1). Furthermore, the impact of soil tillage was negligible regardless of the rotation type involved (Fig. 1). Year was a strong factor affecting field pea yields (Table 2), which strongly and progressively decreased by about $3500 \mathrm{~kg} \mathrm{ha}^{-1}$ during the twelve years of this study (Fig. 1).

\subsubsection{Canola}

Rotation types had minor impact on canola yields during the twelve years (Table 2 and Fig. 1), likely because canola monoculture trials were not performed during this study. As for barley and field pea, soil tillage had minimal and inconsistent effects on canola yields. The effect of tillage was

minimal during seven years (out of twelve), whereas CP decreased yields by about $500 \mathrm{~kg} \mathrm{ha}^{-1}$ in 2001 , 2003 and 2004; yields increased by about $200 \mathrm{~kg} \mathrm{ha}^{-1}$ in 2009 and 2010 (Fig. 1). Soil tillage was inconsequential regardless of the rotation type involved (Fig. 1). From year 1 to year 12, canola yields progressively decreased by about $2000 \mathrm{~kg} \mathrm{ha}^{-1}$, except in 2007, when very high yields were obtained from all rotation types and both soil tillage practices (Fig. 1). In fact, 2007 was the first year that canola $\mathrm{RR}^{\circledR}$ was cropped, facilitating weed management only in this first year. Thereafter, canola yields returned to normal (Fig. 1).

\subsection{Soil chemical properties}

Sampling depth was an important factor for many of the measured soil chemical properties (Table 3). The 0-20 cm layer generally had greater concentrations of organic matter, nitrate and phosphorus, than the 20-40 cm layer (Fig. 2). 
The effects of rotation type on soil organic matter at both depths were insignificant (Fig. 2). Soil tillage also had insignificant effect on soil organic matter content during the twelve years of the study (Fig. 2). However, the effectiveness of soil tillage was significant but inconsistent on soil organic matter content among rotation types at both depths. Compared to MP, CP considerably increased soil organic matter content for the C-B-B-P rotation and barley monoculture, whereas the CP decreases in soil organic matter content for the C-B-P-B rotation and pea monoculture (Fig. 2). Rotation cycle (years) was not a substantial factor affecting soil organic matter content (Table 3).

The effect of rotation type on soil nitrate content at either sampling depth was negligible (Fig. 2). Compared to MP, CP significantly increased soil nitrate in the $0-20 \mathrm{~cm}$ layer the first two rotation cycles (first eight years). The latter also increased soil nitrate in the $0-20 \mathrm{~cm}$ layer by about $2 \mathrm{mg} \mathrm{kg}^{-1}$ for the C-B-B-P, C-P-B-B, and C-B-P-B rotations, whereas it had no consequence for the monoculture treatments (Fig. 2). Rotation cycle (years) had significant (Table 3) but inconsistent (Fig. 2) impacts on soil nitrate contents. Although considerable (Table 3), the impacts of sampling date $\left(<1 \mathrm{mg} \mathrm{kg}^{-1}\right)$ on soil nitrate contents were minimal (results not shown).

Rotation type effect was significant on soil phosphorus content (Table 3), which increased in field pea trials and more particularly in field pea monoculture (Fig. 2). Compared to MP, CP increased soil phosphorus content in the $0-20 \mathrm{~cm}$ layer by about $7 \mathrm{mg} \mathrm{kg}^{-1}$ in the last two rotation cycles (last eight years), whereas it had no consequence in the $20-40 \mathrm{~cm}$ layer (Fig. 2). CP also increased the content by about $6 \mathrm{mg} \mathrm{kg}^{-1}$ in the $0-20 \mathrm{~cm}$ layer for all rotation types, except for pea monoculture where soil tillage had minor effect (Fig. 2). Although significant (Table 3), sampling date had minimal impacts $(<1$ $\mathrm{mg} \mathrm{kg}^{-1}$ ) on soil phosphorus content (results not shown).

\subsection{Soil physical properties}


Date of sampling had a strong significant effect for most soil physical properties (Table 4). In comparison with spring sampling, fall sampling had higher soil bulk density $\left(+0.05 \mathrm{~g} \mathrm{~cm}^{-3}\right)$ and mean weight diameter of soil aggregates $(+0.23 \mathrm{~mm})$ (results not shown), highlighting the importance of sampling in the same time-period when comparing soil properties among different treatments.

The effects of rotation type and soil tillage were non-significant on soil water conductivity during the twelve years of the study (Fig. 3). Nevertheless, compared to MP, CP increased this by about $0.03 \mathrm{~cm} \mathrm{hr}^{-1}$ for the C-B-B-P and barley monoculture, whereas it had insignificant effect for any other rotation type (Fig. 3). Soil water conductivity significantly decreased by $0.017 \mathrm{~cm} \mathrm{hr}^{-1}$ between rotation cycles 1 and 3 (Fig. 3).

Rotation type had insignificant effect on soil bulk density for all rotation cycles (Fig. 3). Soil tillage effect was significant (Table 4) but inconsistent (Fig. 3). Compared to MP, CP significantly increased soil bulk density in the first rotation cycle, but decreased it in the third and last cycles (Fig. 3). Moreover, compared to MP, CP decreased soil bulk density by about $0.03 \mathrm{~g} \mathrm{~cm}^{-3}$ for the C-B-B-P and barley monoculture and increased it by about $0.04 \mathrm{~g} \mathrm{~cm}^{-3}$ for the C-P-B-B and pea monoculture (Fig. 3). Rotation cycle (years) significantly affected soil bulk density (Table 4), as it increased by about $3 \%$ (from 1.22 to $1.25 \mathrm{~g} \mathrm{~cm}^{-3}$ ) between rotation cycles 1 and 3 (Fig. 3).

The impact of rotation type on soil water content was negligible (Fig. 3). Soil tillage had minimal but substantial effect as MP tended to slightly increase soil water content compared to CP the first two rotation cycles (Fig. 3). Compared to MP, CP increased soil water content by $0.02 \mathrm{~g} \mathrm{~g}^{-1}$ for the C-B-B-P rotation, but decreased it by $0.03 \mathrm{~g} \mathrm{~g}^{-1}$ for the pea monoculture (Fig. 3). Rotation cycle (years) was a dominant factor affecting soil water content (Table 4); climate conditions (precipitation and evapotranspiration) may explain this effect. 
Rotation type did not significantly affect soil macro-aggregate $(2-6 \mathrm{~mm})$ stability to water or mean weight diameter (Table 4 and Fig. 4). Comparatively to MP, CP decreased the $<0.25 \mathrm{~mm}$ aggregates the last two rotation cycles by about $8 \%$ (Fig. 4). Furthermore, compared to MP, CP increased the macro-aggregates $(2-6 \mathrm{~mm})$ and mean weight diameter by about $15 \%$ and $0.09 \mathrm{~mm}$, respectively (Fig. 4). Similar results were observed among rotation types where CP improved soil macro-aggregates stability to water and mean weight diameter, except for field pea monoculture where soil tillage effect was not significant (Fig. 4). Rotation cycle was a dominant factor impacting on soil aggregate stability to water (Table 4). Indeed, from cycle 1 to cycle 3, the 2-6 mm aggregates decreased by $2.54 \mathrm{~g}$ per $100 \mathrm{~g}$, the $<0.25 \mathrm{~mm}$ aggregates increased by $5.76 \mathrm{~g}$ per $100 \mathrm{~g}$, and therefore mean weight diameter decreased by about $0.15 \mathrm{~mm}$ (Fig. 4).

\section{Discussion}

\subsection{Soil tillage}

Our study showed that soil tillage impacts on grain yield may vary depending on the year but not on the crop or rotation used. Indeed, our results showed that CP performed equivalently to MP regardless of the rotation. Furthermore, $63 \%$ of the time ( 7 to 8 years out of 12 ) soil tillage did not affect grain yield and when it did, CP sometimes increased and sometimes decreased grain yields (showing inconsistency), and this was not explained by the weather conditions (results not shown). In northern Alberta, Soon and Arshad (2005) also reported a very limited effect of soil tillage on grain yield. Similarly, a twelve-year study in Germany reported limited impact of soil tillage (MP versus CP) on winter wheat, triticale, oats, silage corn, and oilseed rape yields (Gruber et al., 2012). A recent study in eastern Quebec reported that soil tillage did not significantly affect barley yields (Légère et al., 2013), showing clear long-term agronomic and environmental advantages from using reduced tillage such as CP rather than MP. 
Soil tillage is an important component of the cropping system affecting soil nutrient pools and availability. Our results showed that deeper soil tillage (MP versus CP) tended to reduce soil $\mathrm{N}-\mathrm{NO}_{3}{ }^{-}$

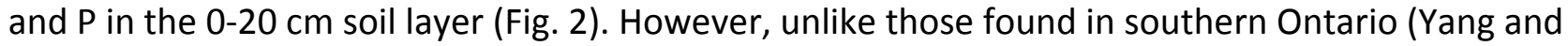
Kay, 2001) and Quebec (Weill et al., 1989), ours results revealed that CP does not significantly raise soil organic carbon in the $0-20 \mathrm{~cm}$ layer compared to MP (Fig. 2). Zheng et al. (2001) also showed increases of labile phosphorus fractions (resin-P) in surface soil with conservation tillage (CP versus $\mathrm{MP}$ ) in Normandin, whereas our long-term study revealed a small but significant impact of soil tillage on soil phosphorus extracted with Mehlich-3 (Fig. 2). A more detailed study such as that done by Zheng et al. (2001), taking into account the effects of soil tillage on various phosphorus and nitrogen forms, would likely be pertinent in order to better understand biochemical fluxes and cycles of such important nutrients in our cropping systems.

Our results demonstrated that the effects of soil tillage on soil physical properties (Table 4). As Angers et al. (1993) and Weill et al. (1989) found earlier in eastern Canada, compared to MP, CP does not significantly affect mean weight diameter compared to MP after four years of soil tillage treatments. However, as our study showed, CP keeps more stable aggregates and greater mean weight diameters after eight years and differences even increase after twelve years (Fig. 4), which demonstrates the necessity of using data from long-term experiments in order to adequately test the effect of soil tillage on soil properties, and possibly, long-term crop yields.

In the literature, reduced tillage has very positive effects on crop growth and yield when used on soils with low organic matter levels and poor "natural" structure (Fageria, 2002). It is therefore possible that our soil (Labarre soil series), which has developed on well-structured marine clay sediments and in a cold climate, does not benefit from reduced tillage as in southern areas. Presumed disadvantages (e.g., yield losses and weed density), or difficulties in changing traditional habits, have 
contributed to the continuance of using MP, especially in highly productive areas and on small farms such as those around Lac-Saint-Jean and along the Saguenay River. As previously demonstrated in Switzerland (Anken et al., 2004), our results revealed that it is possible to reduce tillage depth without substantial reductions in yield and simultaneously improve soil quality.

\subsection{Rotation type}

As for Arshad et al. (1999) and Brandt and Zentner (1995) in semiarid regions of Canada, our study showed that barley yields are about $12 \%$ higher following canola or field pea, indicating the economic benefit of including many annual crops in the rotation. However, unlike what Arshad et al. (1999) reported, barley yields did not perform better after field pea than after canola. Nitrogen fertilization reduced by $25 \mathrm{~kg} \mathrm{~N} \mathrm{ha}^{-1}$ after field pea (CPVQ, 1996) may explain this. Furthermore, as previously demonstrated in Saskatchewan by Malhi et al. (2011), our results indicated a strong negative impact on field pea yields when cropping continuously without rotation (Fig. 1). Canola monoculture was not included in our long-term study simply because of the diseases and pests associated with this monoculture. Therefore, we did not find any significant effect of rotation type on canola yields. Nevertheless, our long-term study showed the positive effects on grain yields of including several cash-crops in a rotation rather than growing them in monoculture.

Our results showed that field pea monoculture strongly increased soil phosphorus content (Fig. 2). Therefore, the agronomic fertilisation standard in Quebec (CPVQ, 1996) that was used likely over-estimated phosphorus needs for field pea. To avoid soil P accumulation in these soils, Lafond and Pageau (2010) recently recommended reducing $\mathrm{P}$ applications by $70 \%$ (up to $35 \mathrm{~kg}_{2} \mathrm{O}_{5}$ ha ${ }^{-1}$ ) for field pea.

Soil organic matter input from plants plays an important role in soil aggregation. Indeed, crops that introduce large amounts of carbon in the soil (as roots and straw) tend to form highly stable soil 
aggregates (Angers and Caron, 1998; Angers and Mehuys, 1990; Carter, 1992; Weill et al., 1989).

Therefore, rotation types did not significantly affect soil water stable aggregates (Fig. 4) likely because they did not affect soil organic matter content (Fig. 2). In La Pocatière, Québec, Angers et al. (1993) also found minor effect of crop rotation on soil aggregate stability. However, Angers and Mehuys (1988) and Lafond et al. (1992) observed better soil aggregation with alfalfa and barley, in comparison to corn. Soil aggregate stability to water is a result of many soil ecosystem interactions involving many direct and indirect interrelations among chemical (e.g., mineralogy, calcium, and salts), physical (e.g., texture, wetting, and drying) and biological (e.g., microorganisms, soil fauna, and arbuscular mycorrhiza) properties of soil (Angers and Caron, 1998). Our results suggested that rotation type has minimal impact on soil chemical and physical properties. Unlike what Chan and Heenan (1996) found in Australia, our canola trials did not create more porous soils (reduced bulk density and increased water infiltration) or more water stable aggregates compared to field pea and barley (Table 4). Furthermore, unlike what Soon and Arshad (2005) found in Alberta, our field pea trials did not produce more residual $\mathrm{N}-\mathrm{NO}_{3}{ }^{-}$in the soil as with barley and canola. The particularly wet and cold climate in the Saguenay-Lac-Saint-Jean area reduces soil organic matter decomposition, which may explain such differences.

\subsection{Rotation cycle}

The results showed that rotation cycles (years) were a dominant factor that strongly affected cash-crop agronomic performances as well as most of the measured soil physical and chemical properties. Cash crops agronomic performances mainly decreased over the twelve years of this experiment (Fig. 1). Many factors such as climate and diseases may explain this. However, climate and diseases do not explain the soil quality decline, as observed by the decreases in soil water conductivity and soil water stable macro-aggregates over this period (Fig.s 3 and 4). Although not 
replicated in this study, one plausible explanation is the initial alfalfa effect on soil quality. Indeed, there are many beneficial agronomic effects from using alfalfa before annual cash-crops. When a perennial alfalfa land is converted to an annual crop, both alfalfa roots and shoots contribute to fresh and labile organic matter in the soil (Angers, 1992; Arshad et al., 2010; Haynes et al., 1991; Martel and Deschênes, 1976), promoting soil macro-aggregation as well as structural stability and water infiltration (Angers and Caron, 1998; Arshad et al., 2010; Chantigny et al., 1997; Fageria, 2002; Perfect et al., 1990; Rasse et al., 2000).

Soil macro-aggregates play an important role in crop nutrient management. A study from Quebec reported that more than $50 \%$ of applied $\mathrm{N}$ was recovered in soil macro-aggregates (> $0.25 \mathrm{~mm}$ ) (Nyiraneza et al., 2010). Therefore, as concluded by these authors, soil macro-aggregates act mainly as a soil nutrient sink for residual fertilizer. Indeed, the decrease in macro-aggregates (as shown in this study, Fig. 4) may explain yield decreases over the rotation cycle. Rasse and Smucker (1998) showed that $41 \%$ of corn roots recolonized root-induced macropores of the previous alfalfa crop, whereas only $18 \%$ was observed in corn after corn, thus gaining access to more water and nutrient resources after alfalfa. Reducing fertilizer applications as well as sustaining high yield potentials are two major agronomic and economic aspects that farmers may benefit from by changing cropping practices in order to maintain as many soil macro-aggregates and root channels as possible. This study suggests that introducing perennial legume crops such as alfalfa into a cash-crop rotation as well as using reduced soil tillage may represent interesting management practices in the northern agricultural context of Saguenay-Lac-Saint-Jean.

\section{Conclusion}

Three-crop rotations instead of monocultures improved barley and field pea yields but had limited impact on soil chemical and physical properties. Compared to other rotations, barley and field 
pea monocultures decreased yields by 600 and $1000 \mathrm{~kg} \mathrm{ha}^{-1} \mathrm{yr}^{-1}$, respectively. Furthermore, using CP as opposed to MP improved soil quality indicators related soil aggregate stability to water, whereas soil tillage had limited impact on crop yields most of the years. This long-term study has helped to identify appropriate farm management practices related to soil tillage and crop rotation specifically adapted to the cold and wet climate of Saguenay-Lac-Saint-Jean.

\section{Acknowledgements}

We would like to thank the Fédération des producteurs de cultures commerciales du Québec and Agriculture and Agri-Food Canada for financing this study. Many thanks also to Promotion Saguenay, the Ministère des Finances du Québec (MFEQ) through its program Créneau ACCORD AgroBoréal, the Ministère de l'agriculture, des pêcheries et de l'alimentation du Québec (MAPAQ) division Saguenay-Lac-Saint-Jean, the Fonds de développement de l'Université du Québec à Chicoutimi, the Conférence régionale des élus Saguenay-Lac-Saint-Jean, and the Union des Producteurs du Québec (UPA) division Saguenay-Lac-Saint-Jean for supporting young researcher establishment. We would also thank the dedicated staff of Agriculture and Agri-Food Canada Research Farm in Normandin; the various teams of summer students, and Denis Anger and Julie É. Guérin for their generous inputs.

\section{References}

Angers, D.A., 1992. Changes in soil aggregation and organic carbon under corn and alfalfa. Soil Science Society of America Journal 56, 1244-1249.

Angers, D.A., Bullock, M.S., Mehuys, G.R., 2008. Aggregate stability to water, In: Carter, M.R., Gregorich, E.G. (Eds.), Soil Sampling and Methods of Analysis. CRC Press, Boca Raton, FL, pp. 811-819.

Angers, D.A., Caron, J., 1998. Plant-induced changes in soil structure: Processes and feedbacks. Biogeochemistry 42, 55-72.

Angers, D.A., Mehuys, G.R., 1988. Effects of cropping on macro-aggregation of a marine clay soil. Canadian Journal of Soil Science 68, 723-732. 
Angers, D.A., Mehuys, G.R., 1990. Barley and alfalfa cropping effects on carbohydrate contents of a clay soil and its size fractions. Soil Biology and Biochemistry 22, 285-288.

Angers, D.A., Samson, N., Legere, A., 1993. Early changes in water-stable aggregation induced by rotation and tillage in a soil under barley production. Canadian Journal of Soil Science 73, 51-59.

Anken, T., Weisskopf, P., Zihlmann, U., Forrer, H., Jansa, J., Perhacova, K., 2004. Long-term tillage system effects under moist cool conditions in Switzerland. Soil and Tillage Research 78, 171-183.

Arshad, M.A., Franzluebbers, A.J., Gill, K.S., 1999. Improving barley yield on an acidic Boralf with crop rotation, lime, and zero tillage. Soil and Tillage Research 50, 47-53.

Arshad, M.A., Soon, Y.K., Ripmeester, J.A., 2010. Quality of soil organic matter and C storage as influenced by cropping systems in northwestern Alberta, Canada. Nutrient Cycling in Agroecosystems 89, 71-79.

Brandt, S.A., Zentner, R.P., 1995. Crop production under alternate rotations on a dark brown Chernozemic soil at Scott, Saskatchewan. Canadian Journal of Plant Science 75, 789-794.

Carter, M.R., 1992. Influence of reduced tillage systems on organic matter, microbial biomass, macroaggregate distribution and structural stability of the surface soil in a humid climate. Soil and Tillage Research 23, 361-372.

Chan, K.Y., Heenan, O.P., 1996. The influence of crop rotation on soil structure and soil physical properties under conventional tillage. Soil and Tillage Research 37, 113-125.

Chantigny, M.H., Angers, D.A., Prévost, D., Vézina, L.P., Chalifour, F.P., 1997. Soil aggregation and fungal and bacterial biomass under annual and perennial cropping systems. Soil Science Society of America Journal 61, 262-267.

CPVQ, 1996. Grilles de référence en fertilisation. AGDEX 540.

Environment Canada, 2013. National Climate Data and Information Archive, http://climate.weatheroffice.gc.ca, August 17th 2013.

Fageria, N.K., 2002. Soil quality vs. environmentally-based agricultural management practices. Communications in Soil Science and Plant Analysis 33, 2301-2329.

Gbur, E.E., Stroup, W.W., McCarter, K.S., Durham, S., Young, L.J., Christman, M., West, M., Kramer, M., 2012. Analysis of generalized linear mixed models in the agricultural and natural resources sciences. American Society of Agronomy, Soil Science Society of America, Crop Science Society of America, Madison, WI.

Gruber, S., Pekrun, C., Möhring, J., Claupein, W., 2012. Long-term yield and weed response to conservation and stubble tillage in SW Germany. Soil and Tillage Research 121, 49-56. 
Hao, X., Ball, B.C., Culley, J.L.B., Carter, M.R., Parkin, G.W., 2008. Soil density and porosity, In: Carter, M.R., Gregorich, E.G. (Eds.), Soil Sampling and Methods of Analysis. CRC Press, Boca Raton, FL, pp. 743-759.

Haynes, R.J., Swift, R.S., Stephen, R.C., 1991. Influence of mixed cropping rotations (pasture-arable) on organic matter content, water stable aggregation and clod porosity in a group of soils. Soil and Tillage Research 19, 77-87.

Holland, J.M., 2004. The environmental consequences of adopting conservation tillage in Europe: Reviewing the evidence. Agriculture, Ecosystems and Environment 103, 1-25.

IBM Corp., 2012. IBM SPSS Statistics for Windows, Version 21.0. Armonk, NY: IBM Corp.

Lafond, J., Angers, D.A., Laverdière, M.R., 1992. Compression characteristics of a clay soil as influenced by crops and sampling dates. Soil and Tillage Research 22, 233-241.

Lafond, J., Pageau, D., 2010. Fertilisation phosphatée et potassique dans la culture du pois sec. Canadian Journal of Plant Science 90, 629-636.

Lafond, J., Ziadi, N., 2011. Fertilisation azotée et phosphatée dans la production du bleuet nain sauvage au Québec. Canadian Journal of Plant Science 91, 535-544.

Lamontagne, L., Nolin, M.C., 1997. Cadre pédologique de référence pour la corrélation des sols. Agriculture et Agroalimentaire Canada. Centre de recherche et de développement sur les sols et les grandes cultures et du Centre de recherche de l'Est sur les céréales et les oléagineux. Bulletin d'extension numéro 7. , p. 70.

Légère, A., Vanasse, A., Craig Stevenson, F., 2013. Low-input management and mature conservation tillage: Agronomic potential in a cool, humid climate. Agronomy Journal 105, 745-754.

Malhi, S.S., Brandt, S.A., Kutcher, H.R., Ulrich, D., 2011. Effects of broad-leaf crop frequency and fungicide application in various rotations on nitrate nitrogen and extractable phosphorus in a dark brown soil. Communications in Soil Science and Plant Analysis 42, 2795-2812.

Martel, Y.A., Deschênes, J.M., 1976. Les effets de la mise en culture et de la prairie prolongée sur le carbone, l'azote et la structure de quelques sols du Québec. Canadian Journal of Soil Science 56, 373383.

Maynard, D.G., Kalra, Y.P., Crumbaugh, J.A., 2008. Nitrate and exchangeable ammonium nitrogen, In: Carter, M.R., Gregorich, E.G. (Eds.), Soil Sampling and Methods of Analysis. CRC Press, Boca Raton, FL, pp. 71-80.

Mehlich, A., 1984. Mehlich-3 soil test extractant. Communications in Soil Science and Plant Analysis $15,1409-1416$.

Nyiraneza, J., Chantigny, M.H., N'Dayegamiye, A., Laverdière, M.R., 2010. Long-term manure application and forages reduce nitrogen fertilizer requirements of silage corn-cereal cropping systems. Agronomy Journal 102, 1244-1251. 
Perfect, E., Kay, B.D., Van Loon, W.K.P., Sheard, R.W., Pojasok, T., 1990. Rates of change in soil structural stability under forages and corn. Soil Science Society of America Journal 54, 179-186.

Rasse, D.P., Smucker, A.J.M., 1998. Root recolonization of previous root channels in corn and alfalfa rotations. Plant and Soil 204, 203-212.

Rasse, D.P., Smucker, A.J.M., Santos, D., 2000. Alfalfa root and shoot mulching effects on soil hydraulic properties and aggregation. Soil Science Society of America Journal 64, 725-731.

Reynolds, W.D., 2008. Saturated hydraulic properties: Laboratory methods, In: Carter, M.R., Gregorich, E.G. (Eds.), Soil Sampling and Methods of Analysis. CRC Press, Boca Raton, FL, pp. 10131024.

Skjemstad, J.O., Baldock, J.A., 2008. Total and organic carbon, In: Carter, M.R., Gregorich, E.G. (Eds.), Soil Sampling and Methods of Analysis. CRC Press, Boca Raton, FL, pp. 225-237.

Soon, Y.K., Arshad, M.A., 2005. Tillage and liming effects on crop and labile soil nitrogen in an acid soil. Soil and Tillage Research 80, 23-33.

Statistique Canada, 2013. Canada's National Statistical Agency.

Tabi, M., Tardif, L., Carrier, D., Laflamme, G., Rompré, M., 1990. Inventaire des problèmes de dégradation des sols agricoles du Québec. Ministère de l'agriculture, des Pêcheries et de l'Alimentation du Québec. Publication no 91-0020.

Topp, G.C., Parkin, G.W., Ferré, P.A., 2008. Soil water content, In: Carter, M.R., Gregorich, E.G. (Eds.), Soil Sampling and Methods of Analysis. CRC Press, Boca Raton, FL, pp. 939-961.

Weill, A.N., De Kimpe, C.R., McKyes, E., 1989. Effect of tillage reduction and fertilizer on soil macroand microaggregation. Canadian Journal of Soil Science 69, 489-500.

Yang, X.M., Kay, B.D., 2001. Rotation and tillage effects on soil organic carbon sequestration in a typic Hapludalf in southern Ontario. Soil and Tillage Research 59, 107-114.

Zheng, Z., Simard, R.R., Lafond, J., Parent, L.E., 2001. Changes in phosphorus fractions of a Humic Gleysol as influenced by cropping systems and nutrient sources. Canadian Journal of Soil Science 81, 175-183. 

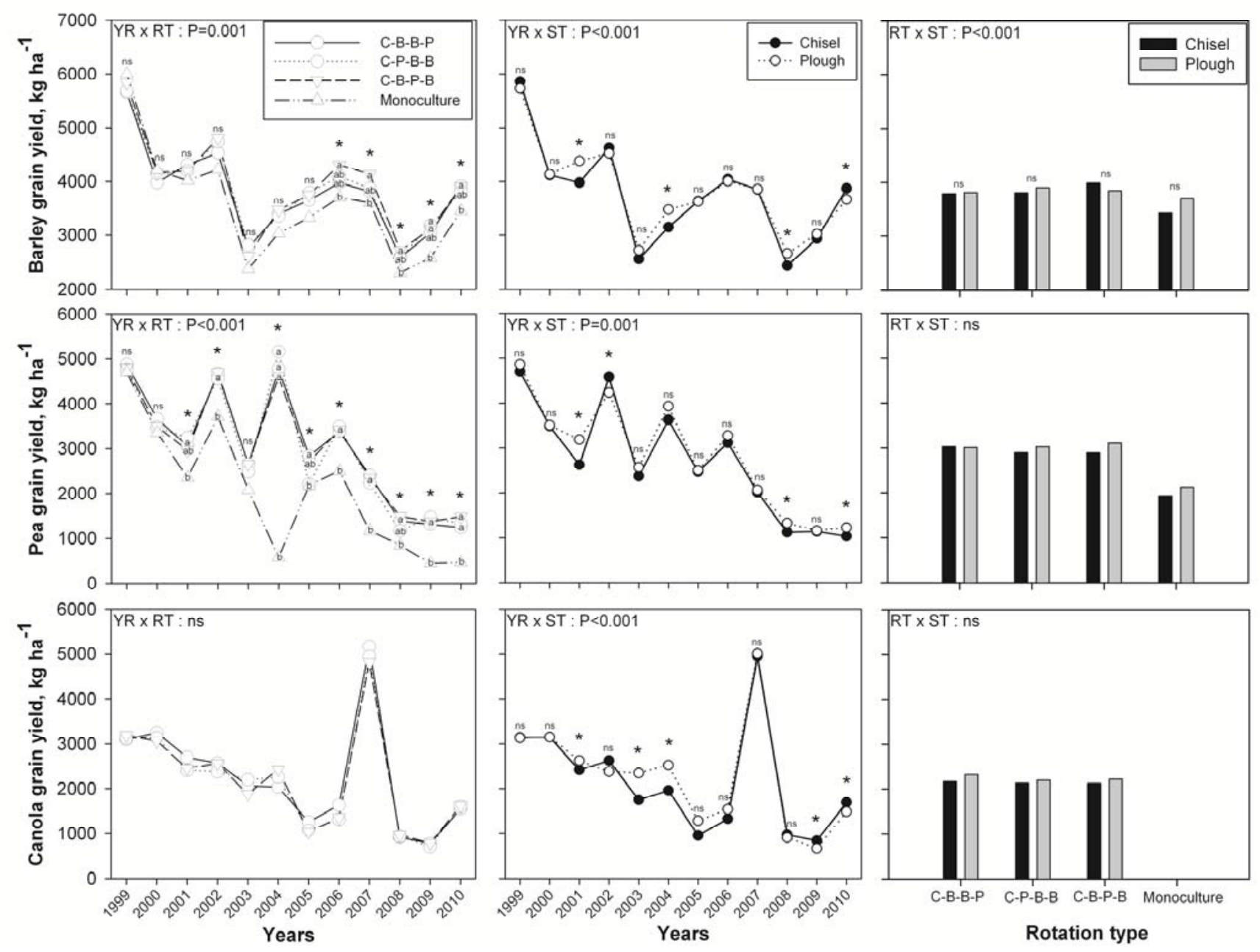

Fig. 1. Year, soil tillage, and rotation type effects on grain yields. Tukey's post-hoc test $(\alpha=0.05)$ was used in order to separate means when ANOVA showed significant effect(s) among rotation types. Asterisks indicate significant difference(s) between means. $C=$ canola. $P=$ field pea. $B=$ barley. $n s=$ not significant. 

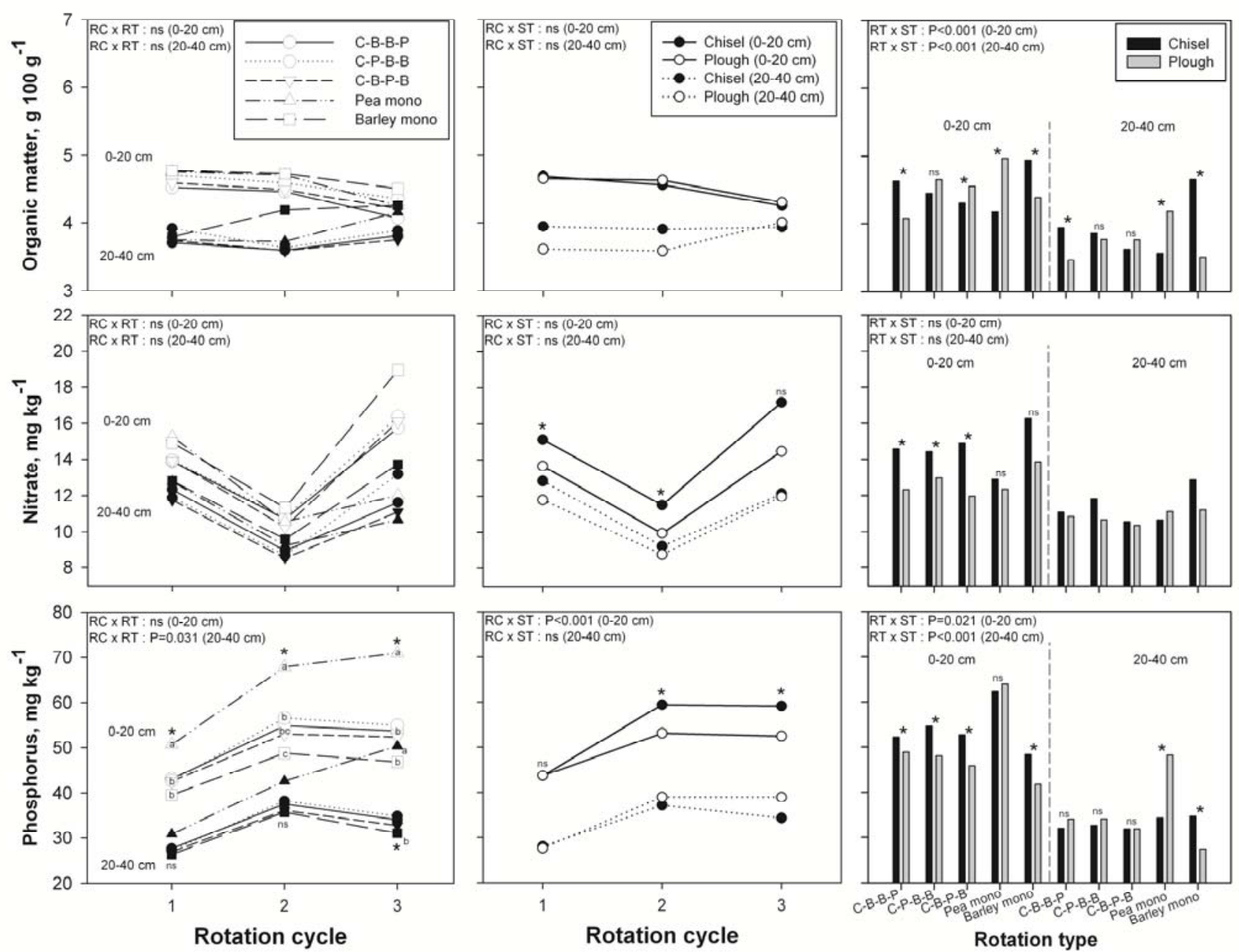

Fig. 2. Rotation cycle, soil tillage, and rotation type effects on soil chemical properties. Tukey's posthoc test $(\alpha=0.05)$ was used in order to separate means when ANOVA showed significant effect(s) among rotation types. Asterisks indicate significant difference(s) between means. $\mathrm{C}=$ canola. $\mathrm{P}=$ field pea. $B=$ barley. $n s=$ not significant. Rotation cycle 1 (1999-2002), 2 (2003-2006), and 3 (2007-2010). 

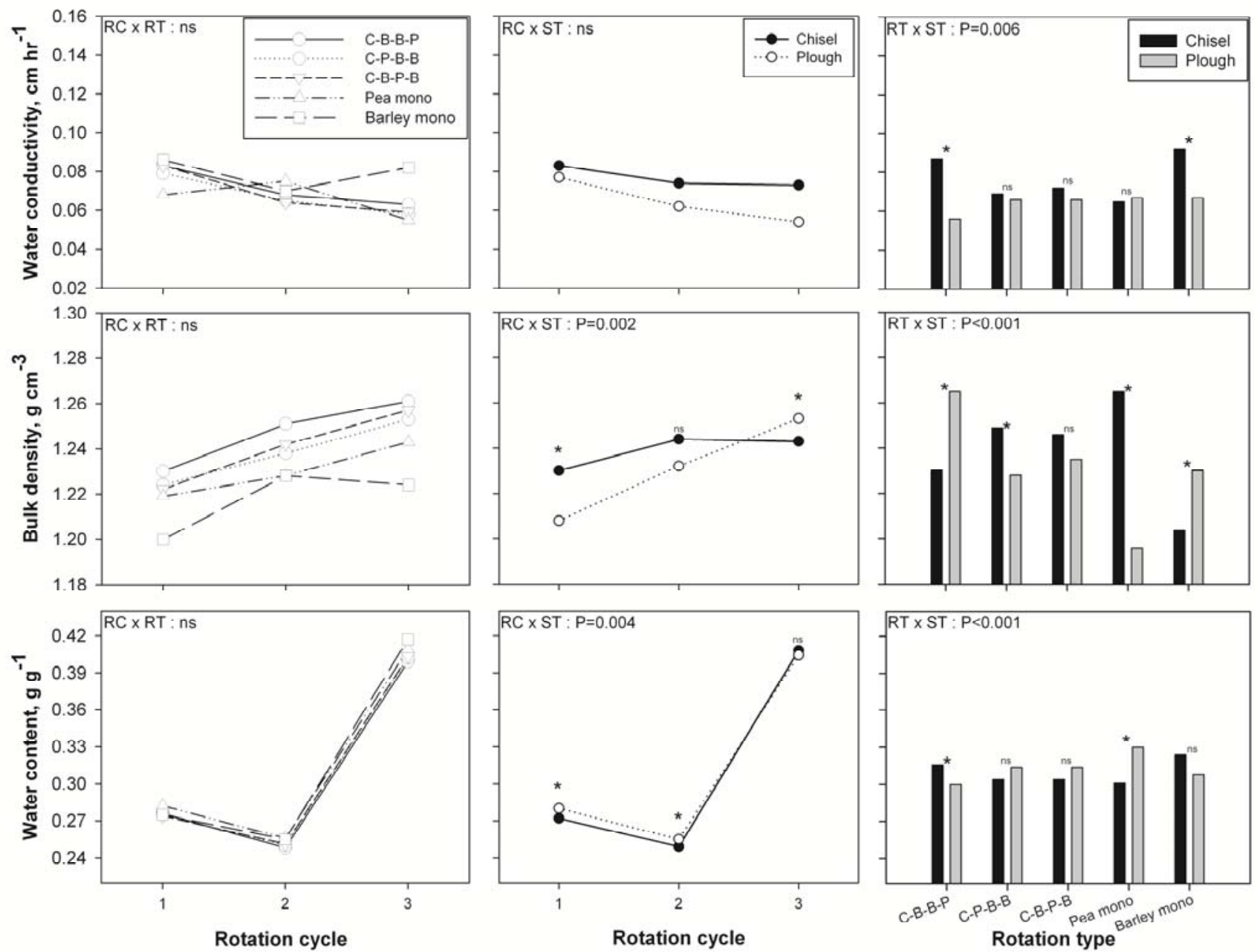

Fig. 3. Rotation cycle, soil tillage, and rotation type effects on soil physical properties. Asterisks indicate significant difference(s) between means. $\mathrm{C}=$ canola. $\mathrm{P}=$ field pea. $\mathrm{B}=$ barley. $\mathrm{ns}=$ not significant. Rotation cycle 1 (1999-2002), 2 (2003-2006), and 3 (2007-2010). 

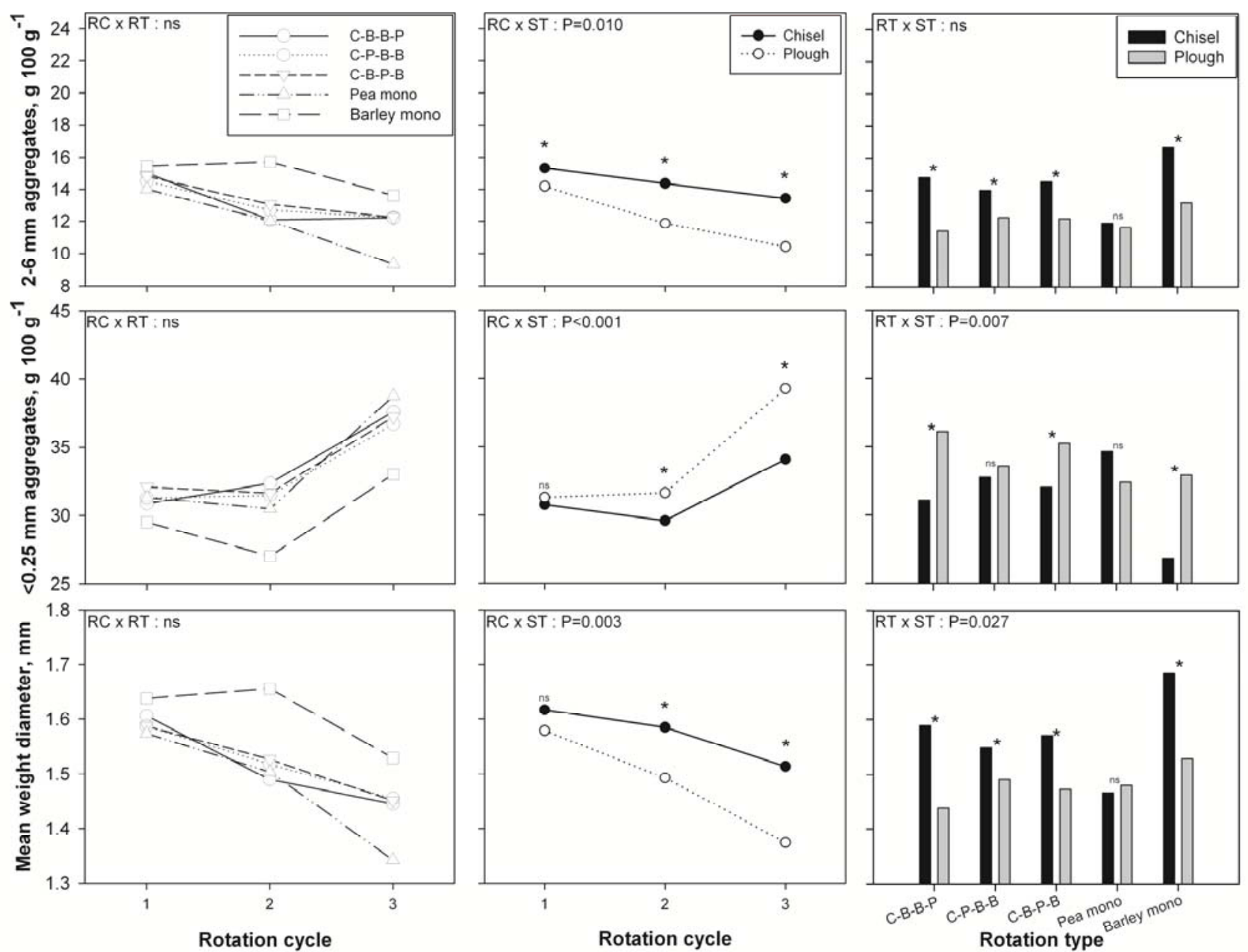

Fig. 4. Rotation cycle, soil tillage, and rotation type effects on soil aggregate stability to water and aggregate mean weight diameter. Asterisks indicate significant difference(s) between means. $\mathrm{C}=$ canola. $P$ = field pea. $B$ = barley. $n s$ = not significant. Rotation cycle 1 (1999-2002), 2 (2003-2006), and $3(2007-2010)$. 
Table 1: Experimental design of the study

\begin{tabular}{|c|c|c|c|c|c|c|c|c|c|c|c|c|c|c|}
\hline \multirow[t]{3}{*}{ Rotation } & \multirow[t]{3}{*}{ Rotation type } & & \multicolumn{4}{|c|}{ Rotation cycle 1} & \multicolumn{4}{|c|}{ Rotation cycle 2} & \multicolumn{4}{|c|}{ Rotation cycle 3} \\
\hline & & \multicolumn{13}{|c|}{--} \\
\hline & & $\begin{array}{c}1995- \\
98\end{array}$ & 1999 & 2000 & 2001 & 2002 & 2003 & 2004 & 2005 & 2006 & 2007 & 2008 & 2009 & 2010 \\
\hline & & & & & & & & -- Cro & & & & & & \\
\hline 1 & \multirow{4}{*}{ C-B-B-P } & Alfalfa & Canola & Barley & Barley & Pea & Canola & Barley & Barley & Pea & Canola & Barley & Barley & Pea \\
\hline 2 & & Alfalfa & Barley & Barley & Pea & Canola & Barley & Barley & Pea & Canola & Barley & Barley & Pea & Canola \\
\hline 3 & & Alfalfa & Barley & Pea & Canola & Barley & Barley & Pea & Canola & Barley & Barley & Pea & Canola & Barley \\
\hline 4 & & Alfalfa & Pea & Canola & Barley & Barley & Pea & Canola & Barley & Barley & Pea & Canola & Barley & Barley \\
\hline 5 & \multirow{4}{*}{ C-P-B-B } & Alfalfa & Canola & Pea & Barley & Barley & Canola & Pea & Barley & Barley & Canola & Pea & Barley & Barley \\
\hline 6 & & Alfalfa & Pea & Barley & Barley & Canola & Pea & Barley & Barley & Canola & Pea & Barley & Barley & Canola \\
\hline 7 & & Alfalfa & Barley & Barley & Canola & Pea & Barley & Barley & Canola & Pea & Barley & Barley & Canola & Pea \\
\hline 8 & & Alfalfa & Barley & Canola & Pea & Barley & Barley & Canola & Pea & Barley & Barley & Canola & Pea & Barley \\
\hline 9 & \multirow{4}{*}{ C-B-P-B } & Alfalfa & Canola & Barley & Pea & Barley & Canola & Barley & Pea & Barley & Canola & Barley & Pea & Barley \\
\hline 10 & & Alfalfa & Barley & Pea & Barley & Canola & Barley & Pea & Barley & Canola & Barley & Pea & Barley & Canola \\
\hline 11 & & Alfalfa & Pea & Barley & Canola & Barley & Pea & Barley & Canola & Barley & Pea & Barley & Canola & Barley \\
\hline 12 & & Alfalfa & Barley & Canola & Barley & Pea & Barley & Canola & Barley & Pea & Barley & Canola & Barley & Pea \\
\hline 13 & $\begin{array}{c}\text { Pea } \\
\text { monoculture }\end{array}$ & Alfalfa & Pea & Pea & Pea & Pea & Pea & Pea & Pea & Pea & Pea & Pea & Pea & Pea \\
\hline 14 & $\begin{array}{c}\text { Barley } \\
\text { monoculture }\end{array}$ & Alfalfa & Barley & Barley & Barley & Barley & Barley & Barley & Barley & Barley & Barley & Barley & Barley & Barley \\
\hline
\end{tabular}


Table 2: F values and probabilities obtained from generalized linear mixed models testing the effects of the year, rotation type, and soil tillage on agronomic performances of annual crops in Normandin, Canada.

\begin{tabular}{|c|c|c|c|}
\hline \multirow[t]{2}{*}{ Model factors } & \multicolumn{3}{|c|}{ Grain yields } \\
\hline & Barley & Field pea & Canola \\
\hline & --------- & lues (Probab & --------- \\
\hline $\mathrm{YR}^{+}$ & $181.0(<0.001)$ & $19.9(<0.001)$ & $271.3(<0.001)$ \\
\hline $\mathrm{RT}^{\ddagger}$ & $2.3(0.217)$ & $8.5(<0.001)$ & $2.2(0.249)$ \\
\hline$S T^{++}$ & $0.6(0.491)$ & $5.8(0.096)$ & $18.1(0.051)$ \\
\hline YR $x$ RT & $3.0(0.001)$ & $27.0(<0.001)$ & $1.4(0.204)$ \\
\hline $\mathrm{YR} \times \mathrm{ST}$ & $5.4(<0.001)$ & $4.0(0.001)$ & $5.6(<0.001)$ \\
\hline $\mathrm{RT} \times \mathrm{ST}$ & $13.4(<0.001)$ & $6.9(0.023)$ & $0.5(0.604)$ \\
\hline YR $x$ RT $\times$ ST & $0.4(0.998)$ & $0.5(0.993)$ & $0.7(0.812)$ \\
\hline
\end{tabular}

† YR: Years (from 1999 to 2010).

¥ RT: Rotation type [(Canola-Barley-Barley-Pea), (Canola-Pea-Barley-Barley), (Canola-Barley-Pea-Barley), (Pea monoculture), and (Barley monoculture)].

†† ST: Soil tillage [(chisel plough) and (moldboard plough)]. 
Table 3: F values and probabilities obtained from generalized linear mixed models testing the effects of rotation cycle, rotation type, soil tillage, sampling date, and sampling depth on soil chemical properties in Normandin, Canada.

\begin{tabular}{|c|c|c|c|}
\hline Model factors & OM & $\mathrm{N}-\mathrm{NO}_{3}^{-}$ & $\mathrm{P}$ \\
\hline & 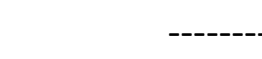 & values (Probabi & -------- \\
\hline $\mathrm{RC}^{+}$ & $0.9(0.413)$ & $101.9(<0.001)$ & $77.4(<0.001)$ \\
\hline $\mathrm{RT}^{\ddagger}$ & $0.1(0.964)$ & $1.1(0.520)$ & $3.1(0.100)$ \\
\hline $\mathrm{ST}^{++}$ & $0.0(0.990)$ & $23.4(<0.001)$ & $0.6(0.470)$ \\
\hline Date ${ }^{\ddagger \ddagger}$ & $1.3(0.273)$ & $14.1(0.011)$ & $5.8(0.029)$ \\
\hline Depth ${ }^{\text {\& }}$ & $19.3(<0.001)$ & $130.2(<0.001)$ & $321.1(<0.001)$ \\
\hline $\mathrm{RC} \times \mathrm{RT}$ & $0.4(0.934)$ & $1.2(0.274)$ & $2.8(0.005)$ \\
\hline $\mathrm{RC} \times \mathrm{ST}$ & $1.5(0.233)$ & $0.9(0.406)$ & $3.7(0.025)$ \\
\hline RC $\times$ Depth & $13.3(<0.001)$ & $3.5(0.030)$ & $2.1(0.123)$ \\
\hline $\mathrm{RT} \times \mathrm{ST}$ & $16.2(<0.001)$ & $0.7(0.573)$ & $9.7(<0.001)$ \\
\hline RT x Date & $0.3(0.904)$ & $2.4(0.052)$ & $0.5(0.762)$ \\
\hline RT x Depth & $0.2(0.936)$ & $0.3(0.874)$ & $3.0(0.018)$ \\
\hline ST $x$ Date & $0.9(0.345)$ & $0.4(0.515)$ & $0.1(0.756)$ \\
\hline ST $\times$ Depth & $2.5(0.114)$ & $10.4(0.001)$ & $34.9(<0.001)$ \\
\hline Date $x$ Depth & $9.7(0.002)$ & $8.5(0.004)$ & $40.6(<0.001)$ \\
\hline
\end{tabular}

† RC: Rotation cycle [(1: 1999-2002), (2: 2003-2006), and (3: 2007-2010)].

‡ RT: Rotation type [(Canola-Barley-Barley-Pea), (Canola-Pea-Barley-Barley), (Canola-Barley-Pea-Barley), (Pea monoculture), and (Barley monoculture)].

†† ST: Soil tillage [(chisel plough) and (moldboard plough)].

¥ Date: Date of sampling [(spring at seeding) and (fall at harvesting)].

\& Depth: Depth of sampling $[(0-20 \mathrm{~cm})$ and $(20-40 \mathrm{~cm})]$. 
Table 4: $F$ values and probabilities obtained from generalized linear mixed models testing the effects of rotation cycle, rotation type, soil tillage, and sampling date on soil physical properties in Normandin, Canada.

\begin{tabular}{|c|c|c|c|c|c|c|c|c|c|}
\hline \multirow[t]{2}{*}{$\begin{array}{l}\text { Model } \\
\text { factors }\end{array}$} & \multirow[t]{2}{*}{ Bulk density } & \multirow{2}{*}{$\begin{array}{c}\text { Water } \\
\text { infiltration } \\
\text { (Ks) }\end{array}$} & \multirow[t]{2}{*}{$\begin{array}{l}\text { Water } \\
\text { content }\end{array}$} & \multicolumn{6}{|c|}{ Soil aggregates } \\
\hline & & & & $2-6 \mathrm{~mm}$ & $1-2 \mathrm{~mm}$ & $0.5-1 \mathrm{~mm}$ & $0.25-0.5 \mathrm{~mm}$ & $<0.25 \mathrm{~mm}$ & $\begin{array}{l}\text { Mean weight } \\
\text { diameter }\end{array}$ \\
\hline $\mathrm{RC}^{+}$ & $35.0(<0.001)$ & $8.7(0.001)$ & $\begin{array}{c}2279.3 \\
(<0.001)\end{array}$ & $14.3(<0.001)$ & $\begin{array}{c}110.1 \\
(<0.001)\end{array}$ & $\begin{array}{c}54.3 \\
(<0.001)\end{array}$ & $86.0(<0.001)$ & $\begin{array}{c}45.0 \\
(<0.001)\end{array}$ & $24.5(<0.001)$ \\
\hline $\mathrm{RT}^{\ddagger}$ & $0.3(0.864)$ & $0.3(0.862)$ & $0.1(0.963)$ & $2.8(0.336)$ & NA & $0.7(0.674)$ & $2.1(0.417)$ & $1.2(0.552)$ & $2.0(0.432)$ \\
\hline $\mathrm{ST}^{++}$ & $0.3(0.632)$ & $3.2(0.131)$ & $0.2(0.690)$ & $18.9(0.005)$ & $1.1(0.323)$ & $0.4(0.578)$ & $2.3(0.154)$ & $4.1(0.098)$ & $10.6(0.020)$ \\
\hline \multirow[t]{2}{*}{ Date ${ }^{\ddagger \neq}$} & 231.4 & $2.3(0.162)$ & $71.2(<0.001)$ & 421.1 & 388.8 & $14.1(0.004)$ & 456.9 & 51.6 & $388.8(<0.001)$ \\
\hline & $(<0.001)$ & & & $(<0.001)$ & $(<0.001)$ & & $(<0.001)$ & $(<0.001)$ & \\
\hline $\mathrm{RC} \times \mathrm{RT}$ & $0.3(0.971)$ & $0.5(0.825)$ & $0.6(0.775)$ & $1.0(0.450)$ & $0.4(0.952)$ & $0.4(0.944)$ & $1.0(0.439)$ & $0.4(0.924)$ & $0.8(0.636)$ \\
\hline $\mathrm{RC} \times \mathrm{ST}$ & $6.3(0.002)$ & $2.7(0.065)$ & $5.5(0.004)$ & $4.6(0.010)$ & $5.7(0.003)$ & $4.9(0.008)$ & $0.2(0.841)$ & $8.0(<0.001)$ & $5.8(0.003)$ \\
\hline $\mathrm{RT} \times \mathrm{ST}$ & $18.6(<0.001)$ & $3.6(0.006)$ & $13.2(<0.001)$ & $2.0(0.088)$ & $1.4(0.217)$ & $2.1(0.075)$ & $0.5(0.703)$ & $3.5(0.007)$ & $2.7(0.027)$ \\
\hline RT $\times$ Date & $0.4(0.830)$ & $0.9(0.460)$ & $0.5(0.738)$ & $0.3(0.876)$ & $0.1(0.980)$ & $0.8(0.502)$ & $1.4(0.219)$ & $0.2(0.949)$ & $0.1(0.974)$ \\
\hline ST x Date & $1.0(0.330)$ & $0.1(0.757)$ & $0.2(0.636)$ & $3.0(0.084)$ & $0.0(0.943)$ & $2.0(0.159)$ & $0.4(0.552)$ & $0.0(0.846)$ & $1.2(0.277)$ \\
\hline
\end{tabular}

† RC: Rotation cycle [(1: 1999-2002), (2: 2003-2006), and (3: 2007-2010)].

‡ RT: Rotation type [(Canola-Barley-Barley-Pea), (Canola-Pea-Barley-Barley), (Canola-Barley-Pea-Barley), (Pea monoculture), and (Barley monoculture)].

†+ ST: Soil tillage [(chisel plough) and (moldboard plough)].

$\ddagger \ddagger$ Date: Date of sampling [(spring at seeding) and (fall at harvesting)]. 